\title{
Nexus between Greenhouse Gas Emissions, Energy Use and Economic Growth: Empirical Evidence From South Asian Countries
}

\author{
Usman Mehmood ${ }^{1,4 *}$, Ali Imran ${ }^{1}$, Aysha Abid ${ }^{1}$, Salman Tariq ${ }^{2}$, Zia ul Haq ${ }^{1}$, \\ Rabiya Mazhar 5 , Asim Daud ${ }^{2}$, Khalid Mahmood ${ }^{2}$, Munawar Iqbal', Adila batool ${ }^{2}$ \\ ${ }^{1}$ Remote Sensing, GIS and Climatic Research Lab (National Center of GIS and Space Applications), \\ Center for Remote Sensing, University of the Punjab, Lahore, Pakistan. \\ ${ }^{2}$ Remote Sensing, GIS and Climatic Research Lab (National Center of GIS and Space Applications), \\ Department of Space Science, University of the Punjab, Lahore, Pakistan. \\ ${ }^{3}$ College of Statistical and actuarial sciences, university of the Punjab, Lahore \\ ${ }^{4}$ Department of Political Science, University of management and technology, Lahore, Pakistan \\ ${ }^{5}$ Department of English, Government college university, Lahore, Pakistan
}

Received: 15 February 2021

Accepted: 18 April 2021

\begin{abstract}
This article explores the nexus between three measures of greenhouse gases $\left(\mathrm{CO}_{2}, \mathrm{~N}_{2} \mathrm{O}\right.$ and $\left.\mathrm{CH}_{4}\right)$ with economic growth (GDP) and energy use for six South Asian countries (Pakistan, India, Nepal, Bangladesh, Sri-Lanka and Bhutan) by using panel ARDL approach from 1990 to 2017. The paper evaluates the three panel models of nitrous oxide $\left(\mathrm{N}_{2} \mathrm{O}\right)$, carbon dioxide $\left(\mathrm{CO}_{2}\right)$ and methane $\left(\mathrm{CH}_{4}\right)$ and studies the relationships with energy use and GDP in the context of (Environmental Kuznets curve) EKC. This study shows non-linear relation of $\mathrm{CO}_{2}$ with GDP as well as of $\mathrm{N}_{2} \mathrm{O}$ with GDP hence proves the presence of EKC in long run. The analysis of the study shows the positive significant impact of $\mathrm{CO}_{2}$ on GDP and energy use in long. In case of short run, the relationship of $\mathrm{CO}_{2}$ with energy use is significant at $10 \%$ level. In case of methane model for long run, there is negative relationship between $\mathrm{CH} 4$ and energy use however, there is positive significant impact between $\mathrm{CH}_{4}$ and GDP. However, there has been negative relationship of $\mathrm{N}_{2} \mathrm{O}$ with energy use and positive insignificant relationship with GDP.
\end{abstract}

Keywords: greenhouse gases, energy use, environmental Kuznets curve, economic growth, South Asia

\section{Introduction}

The rapid rise in the greenhouse gas emission has become the challenge for global community. The

*e-mail: usmanmehmood.umt@gmail.com main cause of GHG emissions is globalization [1-5], which restricts the migration on one side but increases the industrial productions on other side for their international trade purpose [6]. The economic growth is achieved by consuming more energy which is supplied by fossil fuels $[1,3,7,8]$. On one hand, the economic life of people improves due to economic growth but 
on the other, it causes more danger to the social life of people [9]. The environmental depletion is causing severe threat to the life of people all over and world and hence a big challenge for the policymakers [10]. With the passage of time the community realized that in order to remain protected, they must protect their environment. The neat and clean environment is the proof of longer and healthy life. Thus, it is the need of hour to protect our environment to live a healthy and prosperous life.

The situation of environmental degradation in oil importing countries is even more challenging because the oil consumption is causing more $\mathrm{CO}_{2}$, which is the ultimate cause of environmental pollution [11]. The economic activities and more consumption of energy is directly connected with the greenhouse gas emissions because of less efficient energy methods used [12]. These gases have negative impact on the health as well as on the working environment. Poor and developing nations receive the negative impact far earlier as compare to developed nations [14]. Therefore, it has been an accepted challenge by the world community to mitigate the negative effect of environment in order to introduce alternative means of production. Therefore, this study aims to investigate the impacts of GDP and energy use on three green house gases in selected South Asian countries.

The previous studies mainly consider $\mathrm{CO}_{2}$ as $\mathrm{GHG}$ emission for their research purpose [16, 17]. We are considering three factors, which are causing negative shift in the environment and these are nitrous oxide $\left(\mathrm{N}_{2} \mathrm{O}\right)$, methane $(\mathrm{CH} 4)$ and carbon dioxide $\left(\mathrm{CO}_{2}\right)$. These gases are mainly produced due to economic activities [18].
South Asian countries are emerging economically and are considered as most vulnerable to climate changes region in the world [8]. Our study will consider the South Asian countries to investigate the impact of these GHG on the environment of those countries. We are using PMG approach for our study and investigation purpose. Further, we are using EKC to see that it either holds for all components of GHG taken in our study. The study would investigate the long term and shortterm relationship between the variables. The study is important because negative impact of bad environment is not only on human but also on the social potential of society [19]. Two schools of thinking are mainly found in the discussion while we study the literature for economic development and environmental degradation relationships, one is called optimistic school and other one is called pessimistic school [20]. According to the pessimistic approach, the economic growth must be discouraged because they are the main source of environmental degradation. The optimistic school reviews the issue alternatively. They are of opinion that instead of reducing economic activities the countries should opt for environment friendly means of production and transportation [20]. This study is the small step towards the betterment of our environment and opens the new door of further researches. Figs 1 and 2 are showing the spatial distribution of $\mathrm{CO}_{2}$ emissions and Methane over south Asia. We have used AIRS data to show spatial distribution of gases.

\section{Theoretical Consideration}

Environmental Kuznets Curve (EKC) is considered a good tool of realizing that either the environmental

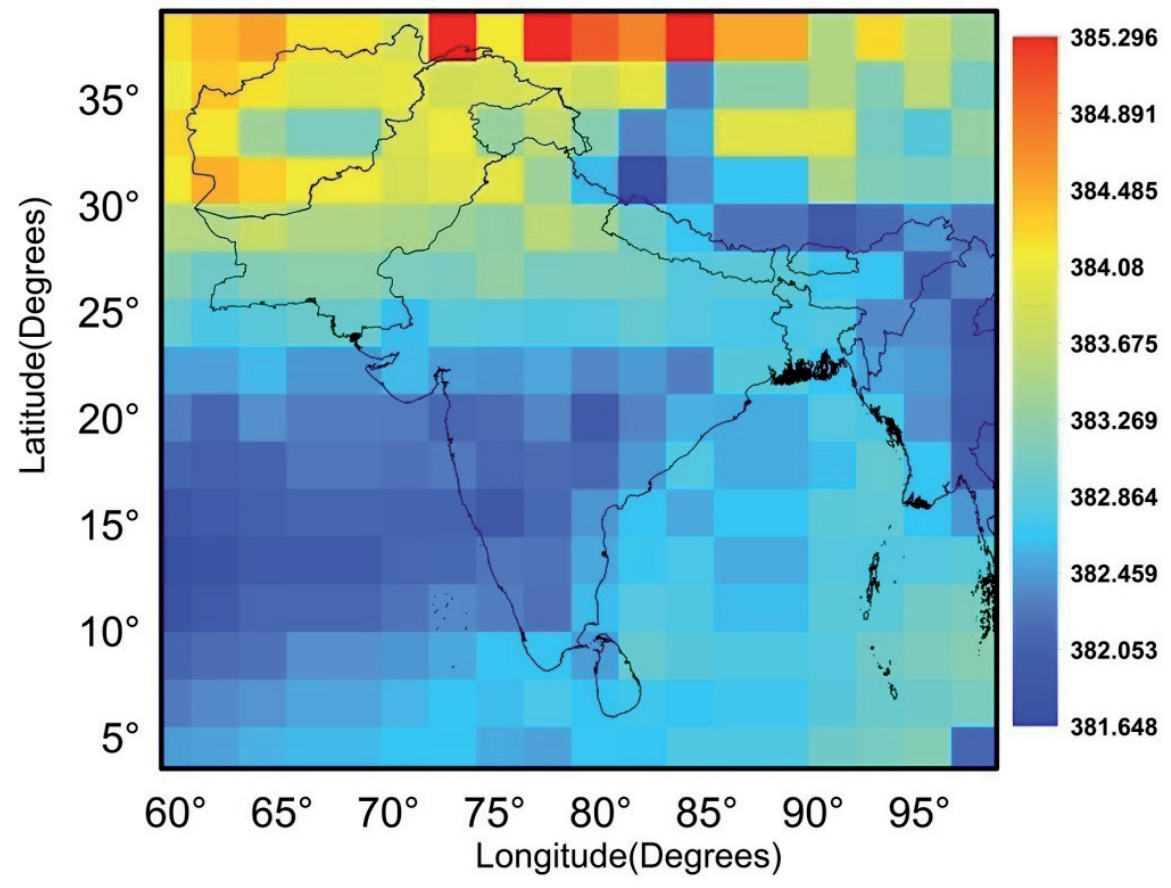

Fig. 1. Satellite derived Spatial distribution of $\mathrm{CO}_{2}$ South Asia. 


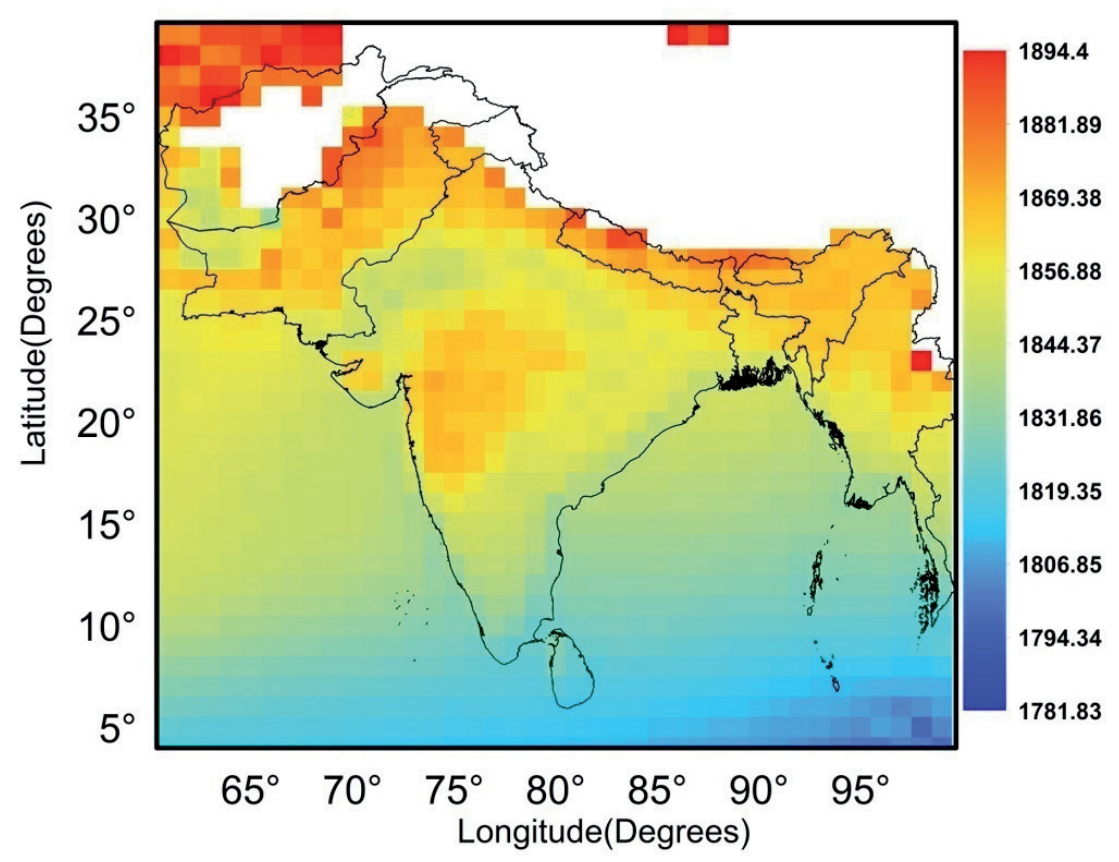

Fig. 2. Satellite derived Spatial distribution of Methane over South Asia.

degradation is declining after some time in connection to the human activities. Human activities are the cause of depletion of environment. When business activities in some particular country or region are increasing then negative shift in the environment cleanliness is observed. EKC shows the nexus of the business activities with the environmental pollution over time. In developing economy, when business activities are rising at the earlier stage the environmental pollution increases side by side but after some period of time due to some controlled factors there comes a decline in the environmental pollution. The credit of EKC goes to Simon Kuznets. Reduction in the environmental pollution is mainly due to alternative and energy efficient use of resources for the production and transportations. Once, the country achieves its optimum level of production and has earned good sources of revenues, it starts understanding the importance of environmental protection thus it probably moves from production industries to the service industries. The complete scenario is explained by EKC.

Once we study the empirical literature about the nexus of GHG and economic growth, we find mixed findings about their relationships. Few studies find positive impact between the variables, few find negative impact between them and there are also who says that no impact is found between them. It is probably varying because of different regions and data sets. For example Saidi, Apergis et al., Arouri et al., Masih et al., Salahuddin et al., Pao et al. [12, 21-25] investigated that there was a positive impact between energy consumption and carbon emission, which resulted in environmental depletion. On the other hand Acheampong et al. [26] tested and showed that there was negative relationship between energy consumption and carbon emissions. In relation to the GDP and carbon emissions Saidi et al. Muhammad, Balibey et al., Zaman et al. [12, 27-29] found that there was a positive relation between carbon emission and GDP. It is also interesting to know that Salahuddin et al, Acheampong et al. Gorus et al. Soytas et al. [24, 26, 30, 31] found no relationship between the carbon emissions and GDP.

From the causality point of view Halicioglu et al., Jahangir et al. [32, 33] found that there was short term causality moving from energy consumption to $\mathrm{CO}_{2}$ emissions. From the study of Soytas et al., Omri, Ssali et al., Zhang et al. [31, 34-37] long run causality which was moving in the same direction was found effective. There was also found a bi-directional causality between the above variables as mentioned by $[38,39]$. Further no evidence of causality was found between energy consumptions and carbon emissions by [31]. Recently Yusuf et al. [11] analyzed the impacts of greenhouse gasses on economic growth and energy consumption in selected oil producing African countries. They found that greenhouse gasses significantly affect economic growth. Moreover, energy consumption put insignificant effects on $\mathrm{CO}_{2}$, Methane and $\mathrm{N}_{2} \mathrm{O}$ in the long-run.

The previous works such as Hanif et al., Bakhsh et al., Mahmood et al., Luqman et al., Ali et al. [16, 17, 40-42] only used $\mathrm{CO}_{2}$ for their model. Considering the past literature, this study contributes to the body of literature by incorporating three indicators of environmental pollution such as $\mathrm{CO}_{2}, \mathrm{~N}_{2} \mathrm{O}$ and $\mathrm{CH}_{4}$. Moreover, this study investigates the impacts of energy use and GDP on greenhouse gasses along with the examination of EKC in all three models for South Asia. 
Table 1. Variables and their sources.

\begin{tabular}{|c|c|c|}
\hline Representation & Variables & Source \\
\hline EC & Energy use & World Data Indicators \\
\hline CO & Carbon Dixide & World Data Indicators \\
\hline $\mathrm{N}$ & Nitrous-Oxide & World Data Indicators \\
\hline $\mathrm{G}$ & GDP & World Data Indicators \\
\hline $\mathrm{G}^{2}$ & GDP $^{2}$ & World Data Indicators \\
\hline $\mathrm{ME}$ & Methane gas & World Data Indicators \\
\hline
\end{tabular}

Note: all data is collected from world data indicators

\section{Methodology and Data}

We utilized panel data of 1990-2017 for all variables from world bank. Most of the past literature used $\mathrm{CO}_{2}$ emissions as an indicator of green house gas. Therefore, to extend current wave of knowledge, we used other indicators of greenhouse gases such as methane and nitrous oxide. Table 1 shows the variables description and their sources.

\section{Model Specification}

This paper employed the model specifications of [21] by including other indicators of greenhouse gases to extend the literature. Hence the empirical model of this study is as follows:

$$
\ln G H G_{t}=\beta_{0}+\beta_{1} E C_{t}+\beta_{2} G_{t}+\beta_{3} G_{t}^{2}+\epsilon_{t}(1)
$$

...where GHG represents the disaggregation of carbon dioxide $\left(\mathrm{CO}_{2}\right)$, methane $\left(\mathrm{CH}_{4}\right)$ and nitrous oxide $\left(\mathrm{N}_{2} \mathrm{O}\right)$, EC represents energy consumption, $\mathrm{G}$ and $\mathrm{G}^{2}$ represents GDP and its square term. $\mathrm{G}^{2}$ is included to check EKC.

\section{Estimation Strategy}

This study employed the pool mean group (PMG) approach to estimate long run and short run results. We have taken large panel, which can have endogeinity problems and ARDL approach can take into account endogeinity problems. Therefore, we followed [43] to employ unit root test of [44]. This test consists of residual based Lagrange and can be applied to balanced and unbalanced panel data. Other tests of $[45,46]$ do not provide such flexibility. According to Table 2, we observed mix order of integration of our variables. Energy consumption is integrated at level but all other variables are stationary at first difference. Mix order of integration provides suitability of ARDL application for short and long run values. Following are the model specifications for panel model:

The model for panel data is as follows: where $t$ is time span and i shows group of economies.

$$
G H G_{2 t}=\sum_{j=1}^{r} \delta_{i j} G H G_{2 i t-j}+\sum_{j=0}^{s} \gamma_{i j}^{\prime} X_{i t-j}+\mu_{i t}+\epsilon_{i t}
$$

In the above mentioned model, $x_{i t}(\mathrm{k} \times 1)$ represent energy use (EN), economic growth $(\mathrm{G})$, and its square term and $\mu_{i t}$ represent the fix effect. ECT shows the stability of the model as follows:

$$
\begin{aligned}
\Delta C O_{2 i t}= & \emptyset_{i}\left(C O_{2 i t-1}-\emptyset_{i}^{\imath} X_{i t-1}\right) \sum_{j-1}^{p-1} \Lambda_{i j}^{\star} \Delta C O_{2 i t-1} \\
& +\sum_{j=0}^{Q=1} \delta_{i j}^{* *} \Delta X_{i t-j}+\mu_{i}+\varepsilon_{i t}
\end{aligned}
$$

...where, $\emptyset_{i}=-\left(1-\sum_{j=1}^{P} \lambda_{i j}\right), \quad \emptyset_{i}^{\prime}=\sum_{j=0}^{Q}\left(\frac{\delta_{i j}}{1-\sum k} \wedge_{i k}\right)$, $\wedge_{i j}^{\star}=-\sum_{m=j+1}^{P} ᄉ_{i m} j=1,2,3, \ldots \ldots, P-1 \quad$ and $\delta_{i j}^{*}=-\sum_{m=j+1}^{Q} \delta_{i m} j=1,2,3 \ldots . Q-1 . \emptyset_{i}$ shows the speed of adjustment.

\section{Results and Discussion}

We start by employing unit root test by [44] and results are presented in Table 2. If Hadri statistics is greater than critical value, we can reject the null hypothesis of unit root existence. The findings show that except energy consumption all variables are integrated at first difference. The mixed order of integration provides suitability of panel ARDL to find short and long run coefficients.

Table 2. Unit root test.

\begin{tabular}{|c|c|}
\hline \multicolumn{2}{|c|}{ Variables } \\
\hline $\mathrm{EC}$ & $8.25^{* * *}$ \\
\hline $\mathrm{CO}$ & $8.21^{* * *}$ \\
\hline $\mathrm{N}$ & $7.83^{* * *}$ \\
\hline $\mathrm{G}$ & $8.87 * * *$ \\
\hline $\mathrm{G}^{2}$ & $8.89 * * *$ \\
\hline $\mathrm{ME}$ & $7.01 * * *$ \\
\hline
\end{tabular}

Note: $* * *$ shows the significant level at $1 \%$

Sources: Author's estimations

Table 3. Kao Residual cointegration test.

\begin{tabular}{|c|c|c|}
\hline & t-statistic & prob. \\
\hline ADF & $-2.27 * * *$ & 0.0113 \\
\hline Residual variance & 0.0102 & \\
\hline HAV variance & 0.0101 & \\
\hline
\end{tabular}

Note: *** shows the significant level at $1 \%$

Sources: Author's estimations 
Table 4. Hausman test.

\begin{tabular}{|c|c|c|}
\hline & Chi square & prob \\
\hline PMG vs MG & 1.75 & 0.62 \\
\hline PMG vs DFE & 1.80 & 0.61 \\
\hline
\end{tabular}

Sources: Author's estimations

Table 5. Panel ARDL estimation for $\mathrm{CO}_{2}$ as dependent variable.

\begin{tabular}{|c|c|c|}
\hline Variables & PMG (LR) & PMG (SR) \\
\hline ECT & $0.428419^{* * *}$ & \\
\hline EC & $\begin{array}{c}0.986781^{* * *} \\
(0.1095)\end{array}$ & \\
\hline G & $\begin{array}{c}1.6107 * * * \\
(0.277388)\end{array}$ & \\
\hline \multirow{2}{*}{$\mathrm{G}^{2}$} & $-0.025484 * * *$ & \\
& $(0.001304)$ & \\
\hline \multirow{2}{*}{ EC } & & $0.590828^{* *}$ \\
& & $(0.3352)$ \\
\hline \multirow{2}{*}{$\mathrm{G}$} & & 4.7365 \\
& & $(9.4798)$ \\
\hline \multirow{2}{*}{$\mathrm{G}^{2}$} & & -0.130623 \\
& & $(0.100950)$ \\
\hline
\end{tabular}

Note: $* * *$ shows the significant level at $1 \%$

Sources: Author's estimations

Table 6. Panel ARDL estimation for methane as dependent variable.

\begin{tabular}{|c|c|c|}
\hline Variables & PMG (LR) & PMG (SR) \\
\hline \multirow{2}{*}{ ECT } & $\begin{array}{c}-0.1486^{* * *} \\
(0.078326)\end{array}$ & \\
\hline \multirow{2}{*}{$\mathrm{EC}$} & $\begin{array}{c}-0.030767 \\
(0.4795)\end{array}$ & \\
\hline \multirow{2}{*}{$\mathrm{G}$} & $\begin{array}{c}30.09092^{* * *} \\
(9.5316)\end{array}$ & \\
\hline \multirow{2}{*}{$\mathrm{G}^{2}$} & $-0.142135^{* * *}$ & \\
& $(0.179463)$ & \\
\hline \multirow{2}{*}{$\mathrm{EC}$} & & -0.072803 \\
& & $(0.117635)$ \\
\hline \multirow{2}{*}{$\mathrm{G}$} & & 5.556907 \\
& & $(11.15802)$ \\
\hline \multirow{2}{*}{$\mathrm{G}^{2}$} & & 0.014805 \\
& & $(0.076144)$ \\
\hline
\end{tabular}

Note: $* * *$ shows the significant level at $1 \%$

Sources: Author's estimations

\section{Co-Integration Test}

In order to check for the existence of co-integration among the variables, we employed Kao test by [47]. Table 3 provides the test results of Kao test. It is evident that null hypothesis of no co-integration is rejected
Table 7. Panel ARDL estimation for nitrous oxide as dependent variable.

\begin{tabular}{|c|c|c|}
\hline Variables & PMG (LR) & PMG (SR) \\
\hline ECT & $\begin{array}{c}-0.318451 * * * \\
(0.115840)\end{array}$ & \\
\hline EC & $\begin{array}{c}0.304313^{* * *} \\
(0.111066)\end{array}$ & \\
\hline $\mathrm{G}$ & $\begin{array}{c}1.159343^{* * *} \\
(0.207558)\end{array}$ & \\
\hline $\mathrm{G}^{2}$ & $\begin{array}{c}-0.005555^{* * *} \\
(0.001004)\end{array}$ & \\
\hline $\mathrm{EC}$ & & -0.067804 \\
& & $(0.219483)$ \\
\hline $\mathrm{G}$ & & 2.677936 \\
& & $(10.94483)$ \\
\hline $\mathrm{G}^{2}$ & & -0.098706 \\
& & $(0.128413)$ \\
\hline
\end{tabular}

Note: $* * *$ shows the significant level at $1 \%$

Sources: Author's estimations

at $1 \%$ level and we can say that there is long run association among our estimated variables.

\section{Hausman Test}

Before the application of Pool mean group (PMG) ARDL, we test for its suitability by conducting Hausman test. For panel estimation, there exist three tests namely: MG, PMG and DFE. Hausman test can guide the most suitable method among these three panel estimations. Table 4 shows the results of Hausman test, which provide suitability of PMG over MG and DFE tests for all three models for $\mathrm{CO}_{2}, \mathrm{~N}_{2} \mathrm{O}$ and $\mathrm{CH}_{4}$ as dependent variables.

\section{Panel ARDL Estimation Results for $\mathrm{CO}_{2}$ as Dependent Variable}

This model takes $\mathrm{CO}_{2}$ as dependent variable and estimate the effect of energy use, GDP and its square term on $\mathrm{CO}_{2}$ emissions. Results are presented in Table 5. According to the PMG results, GDP increases $\mathrm{CO}_{2}$ emissions significantly at $1 \%$ level. This finding is in line with [11]. Energy consumption increases $\mathrm{CO}_{2}$ emissions by $0.98 \%$. GDP square was included in the model to test the EKC as theoretically explained. It is negatively associated with $\mathrm{CO}_{2}$ emissions at $1 \%$ level, which is confirming the EKC. Thus, we can say that in future after getting certain level of economic growth, South Asian countries will start to improve their environmental quality by lowering concentration of $\mathrm{CO}_{2}$ emissions.

Short run estimates show that energy use, GDP and GDP square have insignificant effect on $\mathrm{CO}_{2}$ emissions in the short run. Error correction term (ECT), which calculates the speed of adjustment is -0.42 and significant at $1 \%$ level. 
Panel ARDL Estimation Results for Methane as Dependent Variable

As mentioned earlier, this study contributes to the existing literature by incorporating the other indicators of GHG, therefore, we estimate PMG estimation for $\mathrm{CH}_{4}$ as dependent variable. The results are presented in Table 6. The results show that GDP and energy use contributes to more methane emissions in the long run. This means that higher economic activity will increase more $\mathrm{CH}_{4}$ resulting environmental degradation. Energy consumption is also contributing to more $\mathrm{CH}_{4}$ emissions. This finding is in line with the $\mathrm{CO}_{2}$ model. The square value of GDP is negative and significant at $1 \%$ level confirming the presence of EKC. Thus, we can say that GDP-methane association holds the potential to improve air quality.

Short run estimates show that energy use, GDP and GDP square have insignificant affect on $\mathrm{CH}_{4}$ emissions in the short run. Error correction term (ECT), which calculates the speed of adjustment is -0.14 and significant at $1 \%$ level, which indicates that $14 \%$ improvement towards long term is corrected annually.

\section{Panel ARDL Estimation Results for Nitrous Oxide as Dependent Variable}

We used nitrous oxide as third indicator for environmental degradation. The ARDL model for nitrous oxide is in Table 7. From the results, it can be observed that GDP contributes to more $\mathrm{N}_{2} \mathrm{O}$ in the long run which means that economic activity is increasing $\mathrm{N}_{2} \mathrm{O}$ emissions in South Asian countries. Energy consumption is also increasing $\mathrm{N}_{2} \mathrm{O}$ emissions significantly. These findings are in line with $\mathrm{CO}_{2}$ and Methane models. The square value of GDP is negative and significant at $1 \%$ level confirming the presence of EKC. Thus, we can say that GDP- $\mathrm{N}_{2} \mathrm{O}$ association holds the potential to improve air quality.

Short run estimates show that energy use, GDP and GDP square have insignificant effect on $\mathrm{N}_{2} \mathrm{O}$ emissions in the short run. Error correction term (ECT), which calculates the speed of adjustment is -0.31 and significant at $1 \%$ level, which indicates that $31 \%$ improvement towards long term is corrected annually.

\section{Conclusion and Policy Implications}

This research investigates the impacts of economic growth and energy consumption on greenhouse gasses in South Asian countries over the period of 1990-2017. The selection of South Asian countries is due to their high level of greenhouse gasses due to increased economic activity. This research uses different indicators for greenhouse gasses like $\left(\mathrm{CO}_{2}\right.$, $\mathrm{CH}_{4}$, and $\mathrm{N}_{2} \mathrm{O}$ ). Therefore, this study provides a wider look by probing the impacts of GDP and energy use on above mentioned measures of greenhouse gasses.
This research study highlights that energy consumption increases environmental pollution significantly in South Asian countries. South Asia is a developing region and its economies are emerging in term of its economic activities. This region is also among the climatic vulnerable regions of the world.

This work found the evidence for EKC in three models, means that after a threshold level of GDP, the GHGs will start to decrease in South Asian countries. This research presents important policy implications for South Asian countries to reduce the use of fossil fuels in their commercial and domestic use in order to improve air quality. They need to invest more in renewable energy sources. In this regard, research and development expenditures should be enhanced to increase cleaner production. Moreover, by implementing strict regulations on the imports of fossil fuels, by the promotion of clean energy sources with incentives, these countries can improve the air quality.

As discussed above, energy consumption and economic growth are increasing the concentration of green house gases in South Asian countries. There is a dire need to lower the concentration of GHG in these countries by adopting green revolution of plants and trees in urban areas.

Apart from the contribution, there are some limitations of this work. We check the impact of energy use on greenhouse gasses, future research can be done by incorporating different sectors of economy and their impacts on greenhouse gasses. This will help the policy makers to form result oriented policies for cleaner environment.

\section{Conflict of Interest}

The authors declare no conflict of interest.

\section{References}

1. MEHMOOD U., TARIQ S., UL-HAQ Z., MEO M.S. Does the modifying role of institutional quality remains homogeneous in GDP- $\mathrm{CO}_{2}$ emission nexus? New evidence from ARDL approach. Environmental Science and Pollution Research, 1, 2020.

2. MEHMOOD U., TARIQ S. Globalization and $\mathrm{CO}_{2}$ emissions nexus: evidence from the EKC hypothesis in South Asian countries. Environmental science and pollution research, 2020.

3. MEHMOOD U. Globalization-driven $\mathrm{CO}_{2}$ emissions in Singapore: an application of ARDL approach. Environmental Science and Pollution Research, 2020.

4. MEHMOOD U. Renewable-nonrenewable energy: institutional quality and environment nexus in South Asian countries, 2021.

5. MEHMOOD U. The interactional role of globalization in tourism- $\mathrm{CO}_{2}$ nexus in South Asian countries, 2021.

6. MEHMOOD U. Renewable-nonrenewable energy: institutional quality and environment nexus in South Asian 
countries. Environmental Science and Pollution Research, 2021.

7. TARIQ S., UL-HAQ Z., IMRAN A., MEHMOOD U., ASLAM M. U., MAHMOOD K. $\mathrm{CO}_{2}$ emissions from Pakistan and India and their relationship with economic variables. Applied Ecology and Environmental Research, 2017.

8. MEHMOOD U., TARIQ S. Globalization and $\mathrm{CO} 2$ emissions nexus: evidence from the EKC hypothesis in South Asian countries. Environmental Science and Pollution Research, 1, 2020.

9. SHAHBAZ M., MALLICK H., MAHALIK M. K., LOGANATHAN N. Does globalization impede environmental quality in India? Ecological Indicators, 52, 379, 2015.

10. WANG S., LI G., FANG C. Urbanization, economic growth, energy consumption, and $\mathrm{CO}_{2}$ emissions: Empirical evidence from countries with different income levels. Renewable and Sustainable Energy Reviews, 2018.

11. YUSUF A.M., ABUBAKAR A.B., MAMMAN S.O. Relationship between greenhouse gas emission, energy consumption, and economic growth: evidence from some selected oil-producing African countries. Environmental Science and Pollution Research, 2020.

12. SAIDI K., HAMMAMI S. The impact of $\mathrm{CO}_{2}$ emissions and economic growth on energy consumption in 58 countries. Energy Reports, 1, 62, 2015.

13. SCHELLNHUBER H.J., RAHMSTORF S., WINKELMANN R. Why the right climate target was agreed in Paris. Nature Climate Change, 2016.

14. STERN N. The economics of climate change: The stern review. The Economics of Climate Change: The Stern Review, 2007.

15. PANAYOTOU T. Demystifying the environmental Kuznets curve: Turning a black box into a policy tool. Environment and Development Economics, 2 (4), 465, 1997.

16. HANIF I., FARAZ RAZA S.M., GAGO-DE-SANTOS P., ABBAS Q. Fossil fuels, foreign direct investment, and economic growth have triggered $\mathrm{CO} 2$ emissions in emerging Asian economies: Some empirical evidence. Energy, 171, 493, 2019.

17. BAKHSH K., ROSE S., ALI M.F., AHMAD N., SHAHBAZ M. Economic growth, $\mathrm{CO}_{2}$ emissions, renewable waste and FDI relation in Pakistan: New evidences from 3SLS. Journal of Environmental Management, 196, 627, 2017.

18. MLADENOVIĆ I., SOKOLOV-MLADENOVIĆ S., MILOVANČEVIĆ M., MARKOVIĆ D., SIMEUNOVIĆ N. Management and estimation of thermal comfort, carbon dioxide emission and economic growth by support vector machine. Renewable and Sustainable Energy Reviews, 2016.

19. AMJATH-BABU T.S., KRUPNIK T.J., ARAVINDAKSHAN S., ARSHAD M., KAECHELE H. Climate change and indicators of probable shifts in the consumption portfolios of dryland farmers in Sub-Saharan Africa: Implications for policy. Ecological Indicators, 2016.

20. ALAGIDEDE P., ADU G., FRIMPONG P.B. The effect of climate change on economic growth: evidence from SubSaharan Africa. Environmental Economics and Policy Studies, 2016.

21. APERGIS N., PAYNE J.E. The emissions, energy consumption, and growth nexus: Evidence from the commonwealth of independent states. Energy Policy, 2010.
22. AROURI M.E.H., BEN YOUSSEF A., M'HENNI H., RAULT C. Energy consumption, economic growth and $\mathrm{CO}_{2}$ emissions in Middle East and North African countries. Energy Policy, 45, 342, 2012.

23. MASIH A.M.M., MASIH R. A multivariate cointegrated modelling approach in testing temporal causality between energy consumption, real income and prices -with an application to two Asian LDCs. Applied Economics, 1998.

24. SALAHUDDIN M., GOW J. Economic growth, energy consumption and $\mathrm{CO}_{2}$ emissions in Gulf cooperation council countries. Energy, 2014.

25. PAO H.T., TSAI C.M. $\mathrm{CO}_{2}$ emissions, energy consumption and economic growth in BRIC countries. Energy Policy, 2010.

26. ACHEAMPONG A.O. Economic growth, $\mathrm{CO}_{2}$ emissions and energy consumption: What causes what and where? Energy Economics, 74, 677, 2018)

27. MUHAMMAD B. Energy consumption, $\mathrm{CO}_{2}$ emissions and economic growth in developed, emerging and Middle East and North Africa countries. Energy, 2019.

28. BALIBEY M. Relationships among $\mathrm{CO}_{2}$ emissions, economic growth and foreign direct investment and the environmental kuznets curve hypothesis in Turkey. International Journal of Energy Economics and Policy, 2015.

29. ZAMAN K., MOEMEN M.A. el. Energy consumption, carbon dioxide emissions and economic development: Evaluating alternative and plausible environmental hypothesis for sustainable growth. Renewable and Sustainable Energy Reviews, 2017.

30. GORUS M.S., AYDIN M. The relationship between energy consumption, economic growth, and $\mathrm{CO}_{2}$ emission in MENA countries: Causality analysis in the frequency domain. Energy, 2019.

31. SOYTAS U., SARI R., EWING B.T. Energy consumption, income, and carbon emissions in the United States. Ecological Economics, 62 (3-4), 482, 2007.

32. HALICIOGLU F. An econometric study of $\mathrm{CO}_{2}$ emissions, energy consumption, income and foreign trade in Turkey. Energy Policy, 2009.

33. JAHANGIR ALAM M., ARA BEGUM I., BUYSSE J., VAN HUYLENBROECK G. Energy consumption, carbon emissions and economic growth nexus in Bangladesh: Cointegration and dynamic causality analysis. Energy Policy, 2012.

34. OMRI A. $\mathrm{CO}_{2}$ emissions, energy consumption and economic growth nexus in MENA countries: Evidence from simultaneous equations models. Energy Economics, 40, 657, 2013.

35. SSALI M.W., DU J., MENSAH I.A., HONGO D.O. Investigating the nexus among environmental pollution, economic growth, energy use, and foreign direct investment in 6 selected sub-Saharan African countries. Environmental Science and Pollution Research, 2019.

36. ZHANG X.P., CHENG X.M. Energy consumption, carbon emissions, and economic growth in China. Ecological Economics, 2009.

37. MENYAH K., WOLDE-RUFAEL Y. Energy consumption, pollutant emissions and economic growth in South Africa. Energy Economics, 2010.

38. AL-MULALI U., CHE SAB C.N.B. Electricity consumption, $\mathrm{CO}_{2}$ emission, and economic growth in the Middle East. Energy Sources, Part B: Economics, Planning and Policy, 13 (5), 257, 2018.

39. MIRZA F.M., KANWAL A. Energy consumption, carbon emissions and economic growth in Pakistan: Dynamic 
causality analysis. Renewable and Sustainable Energy Reviews, 2017.

40. MAHMOOD N., WANG Z., HASSAN S.T. Renewable energy, economic growth, human capital, and $\mathrm{CO}_{2}$ emission: an empirical analysis. Environmental Science and Pollution Research, 26 (20), 20619, 2019.

41. LUQMAN M., AHMAD N., BAKHSH K. Nuclear energy, renewable energy and economic growth in Pakistan: Evidence from non-linear autoregressive distributed lag model. Renewable Energy, 139, 1299, 2019.

42. ALI R., BAKHSH K., YASIN M.A. Impact of urbanization on $\mathrm{CO}_{2}$ emissions in emerging economy: Evidence from Pakistan. Sustainable Cities and Society, 48, 101553, 2019.

43. PESARAN M.H., PESARAN M.H., SHIN Y., SMITH R.P. Pooled Mean Group Estimation of Dynamic
Heterogeneous Panels. Journal of the American Statistical Association, 1999.

44. RAO Y., HADRI K., BU R. Testing for stationarity in heterogeneous panel data in the case of model misspecification. Bulletin of Economic Research, 62 (3), 209, 2010.

45. LEVIN A., LIN C.F., CHU C.S.J. Unit root tests in panel data: Asymptotic and finite-sample properties. Journal of Econometrics, 2002.

46. PESARAN M.H. Estimation and inference in large heterogeneous panels with a multifactor error structure. Econometrica, 2006

47. KAO C. Spurious regression and residual-based tests for cointegration in panel data. Journal of Econometrics, 90 (1), $1,1999$. 